\title{
The Mana Model
}

Māori tupuna are all rangatira and are all of great significance; their mana contributes to our contemporary identities. Through my mother, I descend from Tamainupō who was a great rangatira of Waikato. According to Barrett (2012), Tamainupō was no ordinary man. He was handsome, he was athletic, he excelled at warlike pursuits and he was a great leader for his people. His achievements throughout his life were so momentous that his name lives on today as the progenitor of my hapū. Through pepeha we, his descendants, acknowledge descent from him. It is through Tamainupō that I can express to others who I am, how I belong and where I belong. His name enables others to utilize their whakapapa to identify their connection to me, if present. This demonstrates that through him I can promote whakawhanaungatanga and, as a result, enable $\mathrm{Te}$ Kotahitanga. Our tupuna leave handsome legacies of achievement for us, their descendants (Cain, Kahu, \& Shaw, 2017). When I stand, it is with Tamainupō's mana that I make my stand, and when I speak, it is with his voice. His great narrative is a living one that I, along with his other descendants, was born to inherit. Spiller, Barclay-Kerr and Panoho (2015) agree that indigenous leaders are the living face of chiefly lines. This demonstrates the relevance of my rangatira and his living narrative of mana that is interwoven within my whānau and me.

Whānau needs to be bound together by their leaders for their betterment and prosperity. According to Burford and Hudson (2009), there is a mutual relationship between rangatira and whānau. They describe one of the roles of rangatira as having to consider the wellbeing of the whānau as 
a whole. In turn, whānau has great reliance on rangatira for achievement. On the other hand, rangatira can achieve through whānau (Leahy, 2015). For whānau to achieve they need rangatira and for rangatira to achieve they need whānau. Whānau and rangatira are one, and it is through Te Kotahitanga that my whānau and I can achieve. I value the importance of whānau in my life and the importance of both positive individual and collaborative contribution and participation for the betterment of the collective.

Whānau is a key vehicle for Māori well-being (Leahy, 2015). Hapū is made up of groups of whānau and iwi is made up of groups of hapū; these groups are all whānau. Therefore, a rangatira's role is to consider the wellbeing of whānau, hapu and iwi as a whole. Rangatira is the whannau, rangatira is the hapu , rangatira is the iwi. The mana of this collective is also the mana of the individual; I am the mana of the Cuthers whānau, I am the mana of the Tamainupō hapū and I am the mana of the Waikato Tainui iwi. My identity is made up of my interconnections between these social groups and the whenua that we have mana over.

Tangata whenua have an affinity with land in a particular area and the nature of this relationship is recognized in the expression 'mana whenua' (Durie, 2001). I was born and raised in Auckland, and moved to Waikato for my wife's work with every intention of returning to Auckland. However, without explicit knowledge of my connection to Waikato through my Ngāti Tamainupō descent, I was drawn to 'this place', to this land where we have lived. It has always 'felt like home', and so we have stayed. After finding out my explicit connection to the whenua, I now understand the reason why. I now realize this 'feeling' as being tacit knowledge.

My identity is interwoven with the whenua. I am the whenua; my whakapapa is the whenua. I am connected to the whenua through whakapapa that live on through story. The stories of my tupuna that lived on this whenua have contributed to my sense of belonging and my mana. We do 
not have full 'ownership' of the whenua anymore and this has previously been difficult and saddening for me, especially when explaining our connection to our whenua to my children. However, through $\mathrm{He}$ Waka Hiringa: Master of Applied Indigenous Knowledge programme, I have been able to view whenua and ownership through a different lens. In her story, Tariana Turia points out that, although the land has been confiscated, it is not the land that belongs to me, it is I who belongs to the land (Leahy, 2015). This indigenous insight spoke volumes to me and has influenced my perception of whenua. It has enabled me to stand up; I belong to the whenua of Ngāti Tamainupō. I am one with the whenua. Mana whenua is the power we draw from our whenua that our ancestors inhabited (Cain et al., 2017). Through Tamainupō, through my whānau and my whenua I am significant and I embody great mana.

Figure 1: Mana Mode1

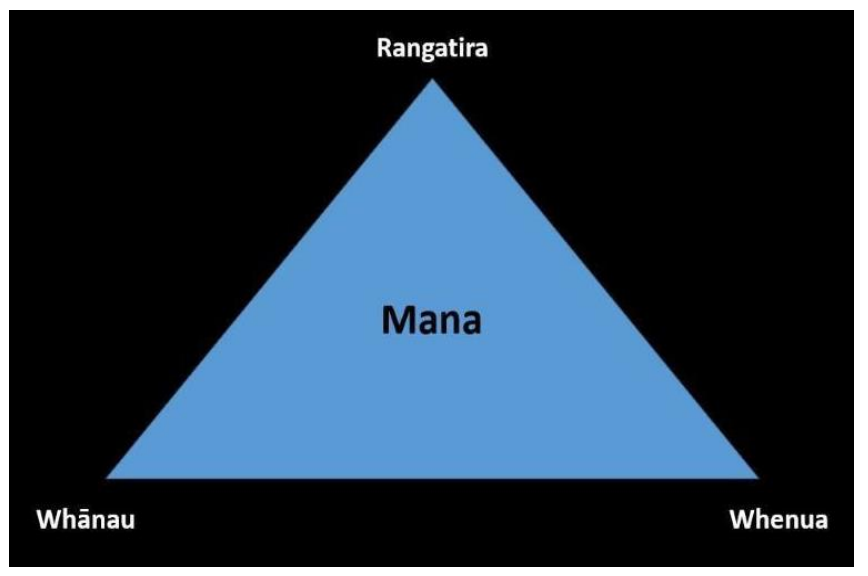

The Mana model about my 'identity', my indigenous practice, and is based on understanding the mana that every indigenous person embodies. 
Understanding the interconnectedness of rangatira, whānau and whenua enables an individual to comprehend the mana they represent. Understanding one's mana is the means to understanding one's identity. Tamainupō is my tupuna and he was a great rangatira. I stand with the mana of Tamainupō and speak with his voice. I am part of Tamainupō's story and he is part of mine. My whānau and hapū belong to Ngāti Tamainupō whenua, and together we belong to the whenua of our Waikato Tainui iwi. We draw mana from our whenua. Through Tamainupō I know how and where I belong, which is significant to my identity. My model of understanding identity enables one to know who they are and what they represent and to enhance pride and mana in themselves. 


\section{REFERENCES}

Barrett, G. (2012). Oral and traditional history volume Ngāti Tamainupō, Kōtara and Te Huaki: An oral history report (Wai 775). Wellington, New Zealand: Crown Forestry Rental Trust.

Burford, G., \& Hudson, J. (2009). Family group conferencing: New directions in community-centred child and family practice. New Jersey, United States of America: Transaction Publishers.

Cain, T., Kahu, E., \& Shaw, R. (2017). Türangawaewae: Identity \& belonging in Aotearoa New Zealand. Auckland, New Zealand: Massey University Press.

Durie, M. (2001). Mauri ora: The dynamics of Māori health. Victoria, Australia: Oxford University Press.

Leahy, H. (2015). Crossing the floor: The story of Tariana Turia. Wellington, Aotearoa New Zealand: Huia Publishers.

Spiller, C., Barclay-Kerr, H., \& Panoho, J. (2015). Wayfinding leadership: Ground breaking wisdom for developing leaders. 